\title{
The transcription factor XBP-1 in neurodegenerative diseases
}

\author{
Frédéric Checler, Eric Duplan, Cristine Alves da Costa \\ From Molecular Neurodegeneration: Basic biology and disease pathways \\ Cannes, France. 10-12 September 2013
}

Parkinson's disease (PD) is a neurodegenerative disorder that is either associated with an autosomal dominant or recessive mode of inheritance. The latter forms are mostly linked to mutations in the genes of parkin, Pink1 and $D J-1$. Several lines of evidence indicate that $D J-1$ could act as an antioxidant while parkin has been characterized as an ubiquitin-ligase. Parkin was reported to interact physically with $D J-1$ monomers in oxidative stress conditions but did not promote its ubiquitinlinked proteasomal degradation. This led us to examine whether parkin could control $D J-1$ via its function as transcription factor that we documented recently [1]. We have shown [2] that parkin controls $D J-1$ by a mechanism independent of its ubiquitin-ligase activity and that this regulation is abolished by PD-related pathogenic mutations. Thus, parkin increases $D J-1$ promoter trans-activation, mRNA levels and protein expression via a transcriptional cascade involving p53 repression and subsequent activation of ER-stress induced X-box-binding protein-1S (XBP-1S). Then, XBP-1S physically interacts with $D J-1$ promoter, thereby raising $D J-1$ mRNA and protein levels. Overall, our study unravels a functional dialogue by which parkin and DJ-1 could control ER-stress response in physiopathological conditions. We will discuss the potential involvement of XBP-1 in other neurodegenerative diseases.

\section{Published: 13 September 2013}

\section{References}

1. da Costa, et al: Nature Cell Biology 2009, 11:1370-1375.

2. Duplan, et al: Journal of Cell Science 2013, 126:2124-2133.

IPMC, UMR7275 CNRS/UNSA, Valbonne, France
doi:10.1186/1750-1326-8-S1-024

Cite this article as: Checler et al:: The transcription factor XBP-1 in neurodegenerative diseases. Molecular Neurodegeneration 2013

8(Suppl 1):O24.
Submit your next manuscript to BioMed Central and take full advantage of:

- Convenient online submission

- Thorough peer review

- No space constraints or color figure charges

- Immediate publication on acceptance

- Inclusion in PubMed, CAS, Scopus and Google Scholar

- Research which is freely available for redistribution
() Bïomed Central

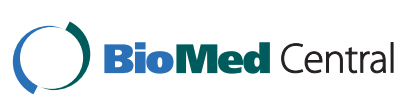

(c) 2013 Checler et al; licensee BioMed Central Ltd. This is an Open Access article distributed under the terms of the Creative Commons Attribution License (http://creativecommons.org/licenses/by/2.0), which permits unrestricted use, distribution, and reproduction in any medium, provided the original work is properly cited. 